\title{
Assessment of Oxidation of Leaves of Ilex paraguariensis (St. Hil)
}

\author{
Rochele Fernanda Molin, Alice Teresa Valduga*, Marco Di Luccio, Nessana Dartora, \\ Alexandre José Cichoski, Mônica Pistore and Elisandra Rigo \\ Universidade Regional Integrada do Alto Uruguai e das Missões; Av. Sete de Setembro, 1621; 99700-000; \\ Erechim - RS - Brasil
}

\begin{abstract}
This work aimed to study the oxidation of leaves of Ilex paraguariensis St. Hil, in a process similar to the oxidation of Camellia sinensis, with the purpose of developing new products based on yerba maté. So far, no previous systematic study about the oxidation of yerba mate has been found elsewhere. A Plackett-Burman experimental design was used for the screening of the significant parameters that affected the oxidation. The oxidation was indirectly quantified by following the changes in the product color, water activity, and $\mathrm{pH}$ with the time of processing. The factors that most influenced the process were the age of the leaves and the relative humidity of the oxidation chamber. The differences between the treatments were more evident after 3, 612 and $24 \mathrm{~h}$ of oxidation. The results could contribute to the developing of new products based on I. paraguariensis St. Hil, increasing the profitability of cultivation of this native species.
\end{abstract}

Key words: physicochemical parameters, yerba maté, leave, extract, experimental design

\section{INTRODUCTION}

The yerba maté (Ilex paraguariensis St. Hil.) is a native species from South America, used in the preparation of tealike beverages such as "chimarrão" in Southern Brazil, maté in Argentina and "tereré" in Paraguay (Costa, 1989; Mazuchowski and Rucker., 1997; Marx et al., 2003). The exploration of I.paraguariensis is an important agricultural activity in Brazil and Argentina due to socioeconomic issues. The yerba maté is able to stimulate the central nervous system due to its content of methylxanthine alkaloids, as caffeine, acids and phenolic compounds with antioxidant activity (Bassani and
Campos, 1997; Saldanha et al., 1999; Deladino et al.; 2007; Bastos et al., 2007). Tealike infusions are worldwide popular and Camellia sinensis infusions (black tea, white tea, green tea, oolong tea) are the most consumed beverages after coffee. The $I$. paraguariensis and $C$. sinensis extracts present very similar active principles, although they belong to distinct species. The processing of C. sinensis for the production of different kinds of tea has been extensively studied (Muthumani and Kumar, 2007; Baruah and Mahanta, 2003; Obanda et al., 2004; Obanda et al., 2001; Bhattacharyya et. al., 2007). The basic process for tea production involves the drying and storage, followed by maceration and oxidation.

*Author for correspondence: valice@uri.com.br 
This work aimed to study the oxidation of leaves of Ilex paraguariensis St. Hil in a process similar to the oxidation of Camellia sinensis, with the purpose of developing new products based on yerba maté. So far, no previous systematic study about the oxidation of yerba maté has been found elsewhere.

\section{MATERIALS AND METHODS}

\section{Experimental design}

The effect of five independent variables (temperature, relative humidity in the oxidation chamber, moisture and age of the leaves and presence/absence of light) on the oxidation of yerba maté leaves was evaluated by a PlackettBurman experimental design (PB) with 12 runs and three repetitions in the central point (Rodrigues and Iemma, 2005). The investigated ranges are listed in Table 1 . The monitored responses were instrumental color, water activity, and $\mathrm{pH}$. The changes in color, water activity and $\mathrm{pH}$ were monitored with time. The variable time was not included in the experimental design, since its effect can mask the effect of other variables. Therefore, the statistical analysis was carried out at each single time.

Table 1 - Range of variables and levels investigated in the Plackett-Burman (PB12) experimental design.

\begin{tabular}{lcccc}
\hline Variable & & $\mathbf{- 1}$ & $\mathbf{0}^{\mathbf{a}}$ & $\mathbf{1}$ \\
\hline Temperature $\left({ }^{\circ} \mathrm{C}\right)$ & $\mathrm{x}_{1}$ & 26 & 33 & 40 \\
Relative humidity (\%) & $\mathrm{x}_{2}$ & 80 & 90 & 99 \\
Age of the leaves $($ months) & $\mathrm{x}_{3}$ & 1 & 6,5 & 12 \\
Moisture of the leaves (\%) & $\mathrm{x}_{4}$ & $30-40$ & $50-60$ & $60-70$ \\
Fluorescent light (W) & $\mathrm{x}_{5}$ & Absent & 150 & 200 \\
\hline
\end{tabular}

${ }^{\mathrm{a} C e n t r a l ~ p o i n t . ~}$

${ }^{\mathrm{b}}$ Age of the leaves were determined by following plant growth after the pruning.

\section{Statistical analysis}

Statistical analysis was performed with the results obtained with the Plackett-Burman experimental design using Statistica (StatSoft Inc., version 6.0). The statistical significance of the regression coefficients was $95 \%$.

\section{Sample collection and preparation}

The yerba maté leaves used in this work were collected from an homogeneous cultivation under direct exposure to sunlight in the geographical coordinates $27^{\circ} 37^{\prime} 15^{\prime \prime}$ 'south, $52^{\circ} 22^{\prime} 47^{\prime \prime}$ west at $765 \mathrm{~m}$ altitude, after a growth pause (November,
December). The leaves were dehydrated for $2 \mathrm{~h}$ using an oven with air circulation at $30^{\circ} \mathrm{C}$ and then were manually ground at room temperature $\left(25^{\circ} \mathrm{C}\right)$ for 5 min (Fig.s 1 a), followed by "rolling" (Liang et al., 2007; Angayarkanni et al., 2002) (Fig. 1b). Figure 1 (c) shows the influence of process rooling on yerba mate leaves.

After rolling, the leaves were transferred to aluminum trays and submitted to the experimental conditions set by the experimental design. Samples were taken from the chamber at time $0,3,6,12,24$ and $48 \mathrm{~h}$ time intervals, subjected to drying and grinding for further physicochemical analysis.
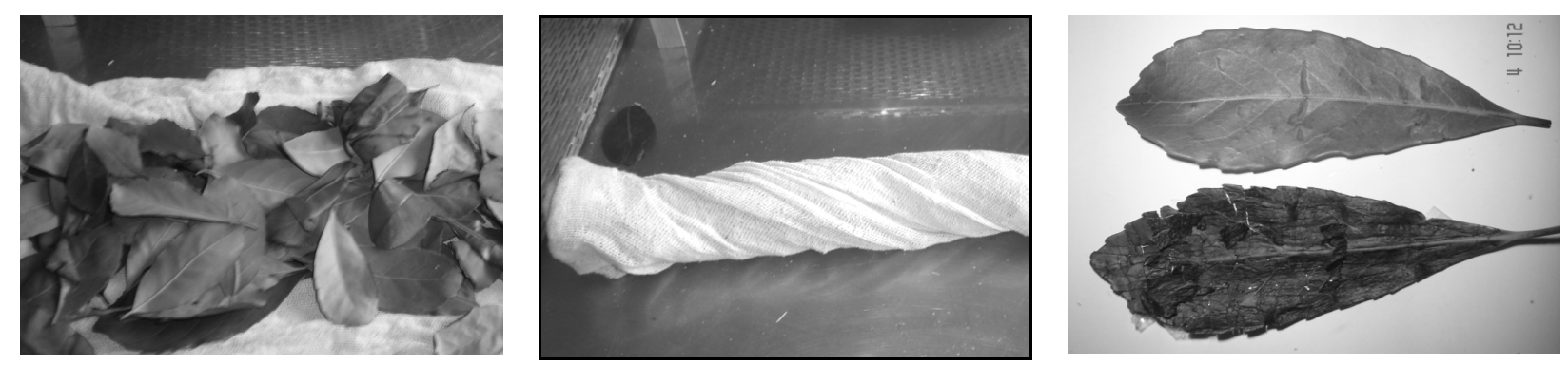

Figure 1 - Dehydrated leaves (a).Rolling process (b).Leaves before rolling (up) and after rolling (below) (c). 


\section{Analytical determinations}

Color

Instrumental color was determined using a colorimeter (Minolta CR400), with light source D65, expressing the results in the CIE Lab color space $\left(\mathrm{L}^{*} \mathrm{a}^{*} \mathrm{~b}^{*}\right)$. Equipment calibration was carried out using a standard white plate. Before measurements, the particle size of samples was standardized to be smaller than $2.35 \mathrm{~mm}$. The samples were placed in a Petri dish $(9 \mathrm{~cm}$ diameter) using the amount of sample necessary to cover completely the bottom of the dish. All the measurements were carried out in triplicates.

\section{Water activity $\left(a_{w}\right)$}

The determination of water activity was carried out with $1 \mathrm{~g}$ of sample in an Aqualab system (Decagon, Model CX-2) at $25^{\circ} \mathrm{C}$. The equipment was previously calibrated with a sodium chloride solution with $\mathrm{a}_{\mathrm{w}} \quad 0.882$, following the recommendations of the equipment's operations manual.

\section{pH}

For $\mathrm{pH}$ analysis, $10 \mathrm{~g}$ of ground leaves were mixed with $100 \mathrm{~mL}$ of deionized water. The $\mathrm{pH}$ of samples was determined with a digital $\mathrm{pH}$ meter (Digimed DMPH-2), calibrated with standard buffers.

\section{RESULTS AND DISCUSSION}

\section{pH}

Most of natural foods are acid, e.g., fruits that present $\mathrm{pH}$ between 3.0 and 4.5 , and vegetables that present $\mathrm{pH}$ between 4.6 and 6.5. The $\mathrm{pH}$ of foods is one of the main factors that influence the growth, survival and/or destruction of native and contaminant microorganisms (Silva, 2000). The matrix of the PB12 experimental design with the real and coded factors with the respective $\mathrm{pH}$ of the samples after the different time of oxidation is shown in Table 2. Figure 2 showed that the major changes in $\mathrm{pH}$ occurred after 6,12 and $24 \mathrm{~h}$ of oxidation. No significant $(\mathrm{p}<0.05)$ differences between the samples were observed at 0,3 and $48 \mathrm{~h}$ of processing. The $\mathrm{pH}$ of I. paraguariensis leaves varied from 5.2 to 6.4. This variation showed a strong effect on the activity of the enzymes in the leaves, since even a decimal variation in $\mathrm{pH}$ could cause a large variation in enzyme activity (Riegel, 2006). Nakasaki et.al. (2008), studying the oxidation of Camelia sinensis, observed that the $\mathrm{pH}$ value was maintained at a weakly acidic level of 5 to 6 throughout the fermentation.

Table 2 - Matrix of the experimental design (coded and real values) with responses in terms of $\mathrm{pH}$.

\begin{tabular}{|c|c|c|c|c|c|c|c|c|c|c|c|}
\hline \multirow{2}{*}{ Run } & \multicolumn{5}{|c|}{ Factors } & \multicolumn{6}{|c|}{ pH } \\
\hline & $\mathbf{X}_{1}$ & $\mathbf{X}_{2}$ & $\mathbf{X}_{3}$ & $\mathbf{X}_{4}$ & $X_{5}$ & $\mathbf{0 h}$ & $3 h$ & $6 h$ & $12 \mathrm{~h}$ & $24 h$ & $48 \mathrm{~h}$ \\
\hline 1 & $1(40)$ & $-1(80)$ & $1(12)$ & $-1(30-40)$ & -1 & 5.9 & 5.9 & 5.3 & 5.7 & 5.8 & 5.7 \\
\hline 2 & $1(40)$ & $1(99)$ & $-1(1)$ & $1(60-70)$ & -1 & 6.2 & 5.7 & 6.4 & 6.4 & 6.5 & 6.5 \\
\hline 3 & $-1(26)$ & 1(99) & $1(12)$ & $-1(30-40)$ & 1 & 5.6 & 5.7 & 5.6 & 5.6 & 5.6 & 5.8 \\
\hline 4 & $1(40)$ & $-1(80)$ & $1(12)$ & $1(60-70)$ & -1 & 5.9 & 6.1 & 5.7 & 5.3 & 5.8 & 6.3 \\
\hline 5 & $1(40)$ & $1(99)$ & $-1(1)$ & $1(60-70)$ & 1 & 6.1 & 6.5 & 6.6 & 6.5 & 6.4 & 5.7 \\
\hline 6 & $1(40)$ & 1(99) & $1(12)$ & $-1(30-40)$ & 1 & 5.6 & 6.2 & 5.9 & 5.8 & 5.8 & 5.5 \\
\hline 7 & $-1(26)$ & 1(99) & $1(12)$ & $1(60-70)$ & -1 & 5.9 & 5.9 & 5.8 & 5.9 & 5.8 & 5.7 \\
\hline 8 & $-1(26)$ & $-1(80)$ & $1(12)$ & $1(60-70)$ & 1 & 5.9 & 6.0 & 5.3 & 5.3 & 6.0 & 6.3 \\
\hline 9 & $-1(26)$ & $-1(80)$ & $-1(1)$ & $1(60-70)$ & 1 & 6.4 & 6.3 & 5.7 & 5.7 & 6.0 & 6.5 \\
\hline 10 & $1(40)$ & $-1(80)$ & $-1(1)$ & $-1(30-40)$ & 1 & 6.4 & 5.8 & 6.4 & 6.3 & 6.2 & 5.8 \\
\hline 11 & $-1(26)$ & 1(99) & $-1(1)$ & $-1(30-40)$ & -1 & 6.1 & 6.2 & 6.2 & 5.7 & 5.8 & 5.6 \\
\hline 12 & $-1(26)$ & $-1(80)$ & $-1(1)$ & $-1(30-40)$ & -1 & 6.0 & 6.0 & 6.4 & 6.5 & 6.3 & 5.8 \\
\hline $13^{*}$ & $0(33)$ & $0(90)$ & $0(6,5)$ & $0(55)$ & 0 & 5.2 & 6.0 & 5.5 & 5.3 & 6.0 & 5.8 \\
\hline $14 *$ & $0(33)$ & $0(90)$ & $0(6,5)$ & $0(55)$ & 0 & 5.6 & 5.7 & 6.0 & 5.9 & 6.2 & 6.3 \\
\hline $15^{*}$ & $0(33)$ & $0(90)$ & $0(6,5)$ & $0(55)$ & 0 & 5.5 & 5.8 & 5.7 & 6.0 & 6.0 & 6.2 \\
\hline
\end{tabular}

*Central point. $\mathrm{X}_{1}=$ Temperature $\left({ }^{\circ} \mathrm{C}\right), \mathrm{X}_{2}=$ Relative humidity of chamber $(\%), \mathrm{X}_{3}=$ Age of the leaves (months), $\mathrm{X}_{4}=$ moisture of the leaves $(\%), \mathrm{X}_{5}=$ light power $(\mathrm{W})$. 


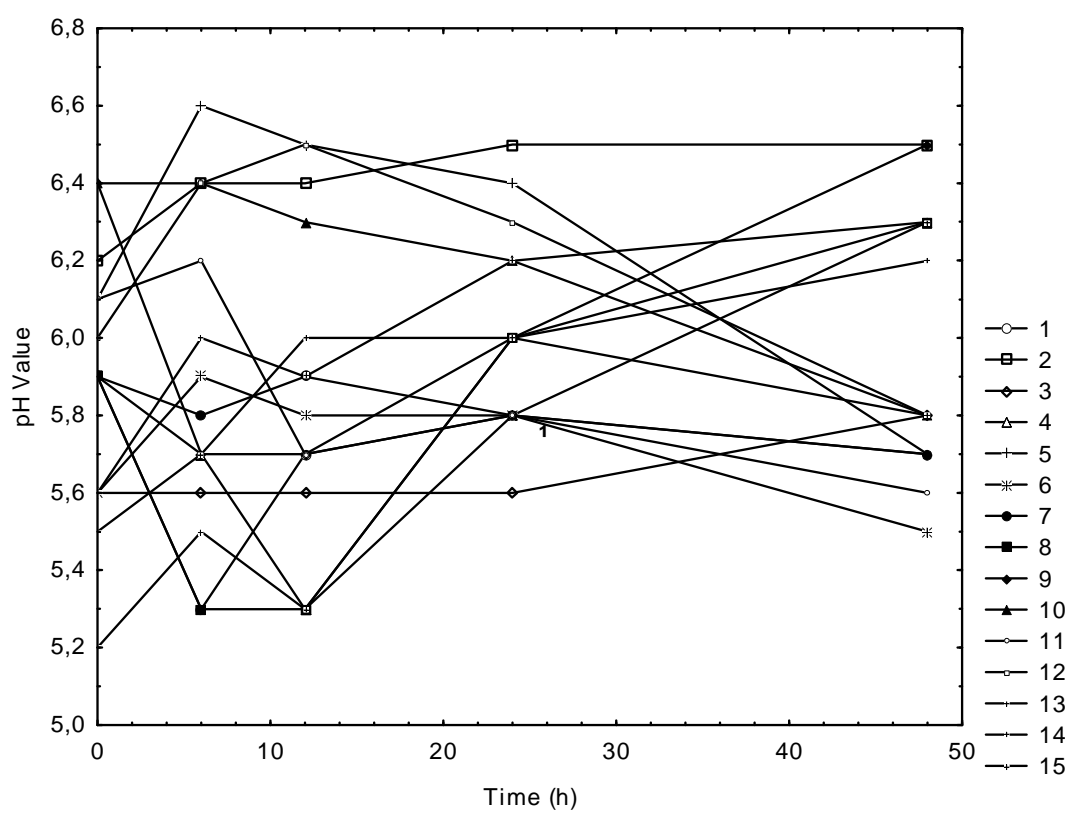

Figure 2 - Kinetic behavior of $\mathrm{pH}$ during oxidation in the different experimental conditions presented in Table 2.

The Pareto chart of effects for $\mathrm{pH}$ after $6 \mathrm{~h}$ of oxidation is presented in Figure 3. The relation between the $\mathrm{pH}$ and moisture of the leaves showed that younger leaves presented an increase in $\mathrm{pH}$ during oxidation, while the $\mathrm{pH}$ of mature leaves tended to decrease during the process. The behavior of $\mathrm{pH}$ at $6,12,24$ and $48 \mathrm{~h}$ of processing was similar to that reported in Figure 3. $\mathrm{pH}$ is an important factor influencing enzyme activity (Lehninger, 2006) and can affect the oxidative enzymes in vegetables (peroxidases and polyphenoloxidases).

Studies with brussels sprouts found as $\mathrm{pH} 9$ the optimal for the activity and stability of polyphenoloxidases (Nagai and Suzuki, 2003).The effect of $\mathrm{pH}$ on the activity of polyphenoloxidases has been extensively studied for fruits, juice and vegetables with preservative agent inhibiting the oxidation of color modifications and browning of explants in tissue culture (Niu et al., 2010; Lin et al., 2010; Wu et al., 2010; Dziki et aL., 2008; Dziki et al.,2007; Delicado et al., 2007; Mayer et al., 2006). However, the relationship between the $\mathrm{pH}$ and polyphenol oxidase activity in the oxidation process the leaves of yerba mate to be utilized in the form of tea is still a recent study.

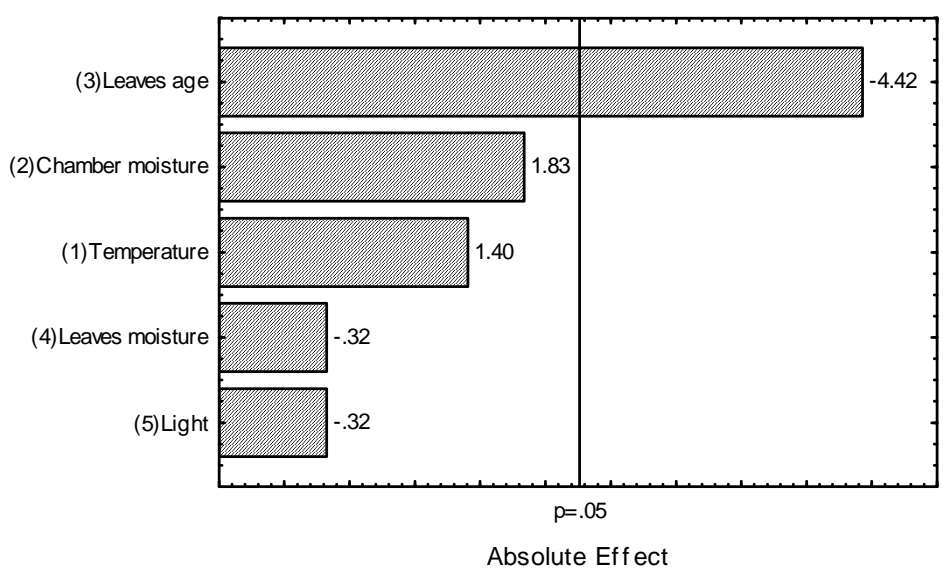

Figura 3 - Pareto chart of effects for $\mathrm{pH}$ after $6 \mathrm{~h}$ of oxidation. 


\section{Water activity $\left(\mathbf{a}_{\mathrm{w}}\right)$}

The water activity varied between 0.623 and 0.996. The main effects of the variables studied was observed in the leaves subjected to $6 \mathrm{~h}$ of oxidation as shown in Figure 4. Similar results were observed to 24 and $48 \mathrm{~h}$. The statistical analysis of the results of $a_{w}$ at 3 and $12 \mathrm{~h}$ did not show statistically significant effects $(\mathrm{p}<0.05)$ on $a_{w}$. It was observed that both the relative humidity of the oxidation chamber and the initial moisture of the leaves positively influenced the water activity, as it would be expected. The magnitude of the effects of both factors were similar (2.58 and 2.43), indicating that they influenced the water activity in the same way. The other factors did not significantly influence this variable.

The relative humidity of the chamber affects the water activity of the leaves, since it is proportional to the partial pressure of water in the air, and the higher the difference in the partial pressure of water between the air and the leaves, the higher the transfer rate of water from the air to the leaves, increasing the water activity in the equilibrium (Ramallo and Albani, 2004).

The water activity directly influences the enzyme activity, and the decrease in $\mathrm{a}_{\mathrm{w}}$ can reduce the action of enzymes (Court, 2006). Lipid oxidation is also affected by the $a_{w}$. When $a_{w}$ varied between 0.2 and 0.8 , the oxidation rate was low when compared to the rates that were obtained when $a_{w}$ tended to 1 . Some values found in the present work could be considered high and could affect the browning of the leave particles.

The water activity also affects the microbial growth. Most of bacteria and fungi cannot grow in water activity lower than 0.91 and 0.80 , respectively (Fennema, 2000). However, microbiological analyses of the samples studied in the present work did now show any growth of such microorganisms during oxidation (date not showed).

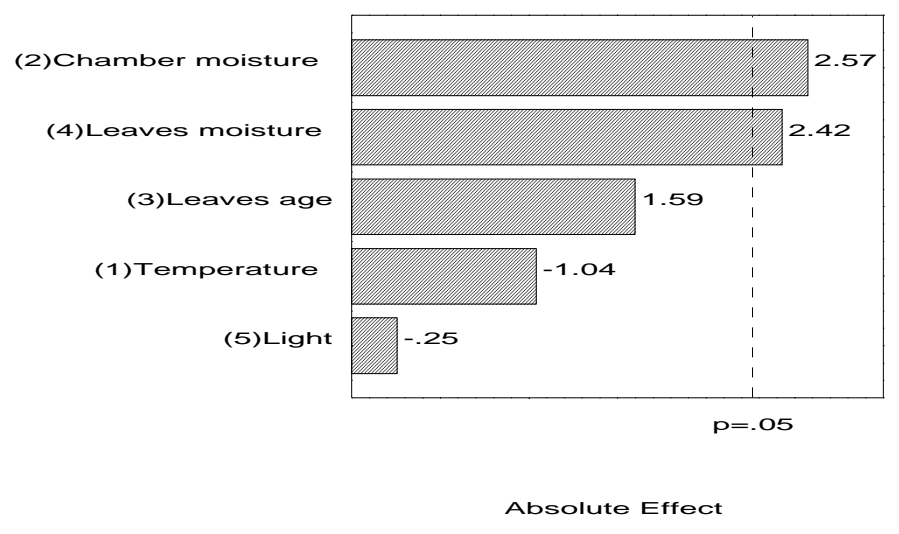

Figure 4 - Pareto chart of effects for $a_{w}$ after 6 h of oxidation.

\section{Color $(\mathbf{L} * \mathbf{a} * \mathbf{b} *)$}

The effects of the studied factors on color, estimated by the parameters $\mathrm{L}^{*}, \mathrm{a}^{*}$ and $\mathrm{b}^{*}$ may be observed in Figures 5, 6 and 7, respectively, in the oxidation times of the $3 \mathrm{~h}, 6 \mathrm{~h}$ and $48 \mathrm{~h}$. The parameter $\mathrm{L}^{*}$ represented the lightness of the sample, in a scale from 0 (black) to 100 (white). The samples from the experimental runs of the PB 12 design presented a variation from 12 to 39, considering all the experimental conditions and time of oxidation. black tea infusions for instance may show L* from 13 to 47 (Liang et al., 2002). The color of the oxidized leaves was directly related to the quality of the final product, since this parameter changed according to the content of pigments, nitrogen and phenolic compounds.

The age of the leaves showed a significant negative effect $(p<0.05)$ on the color of the samples after 3 and $6 \mathrm{~h}$ of oxidation. The negative effect meant that younger leaves were darker than the older leaves, after the above mentioned time of oxidation. The relative humidity of the chamber also influenced negatively the L* (Fig. 5). 

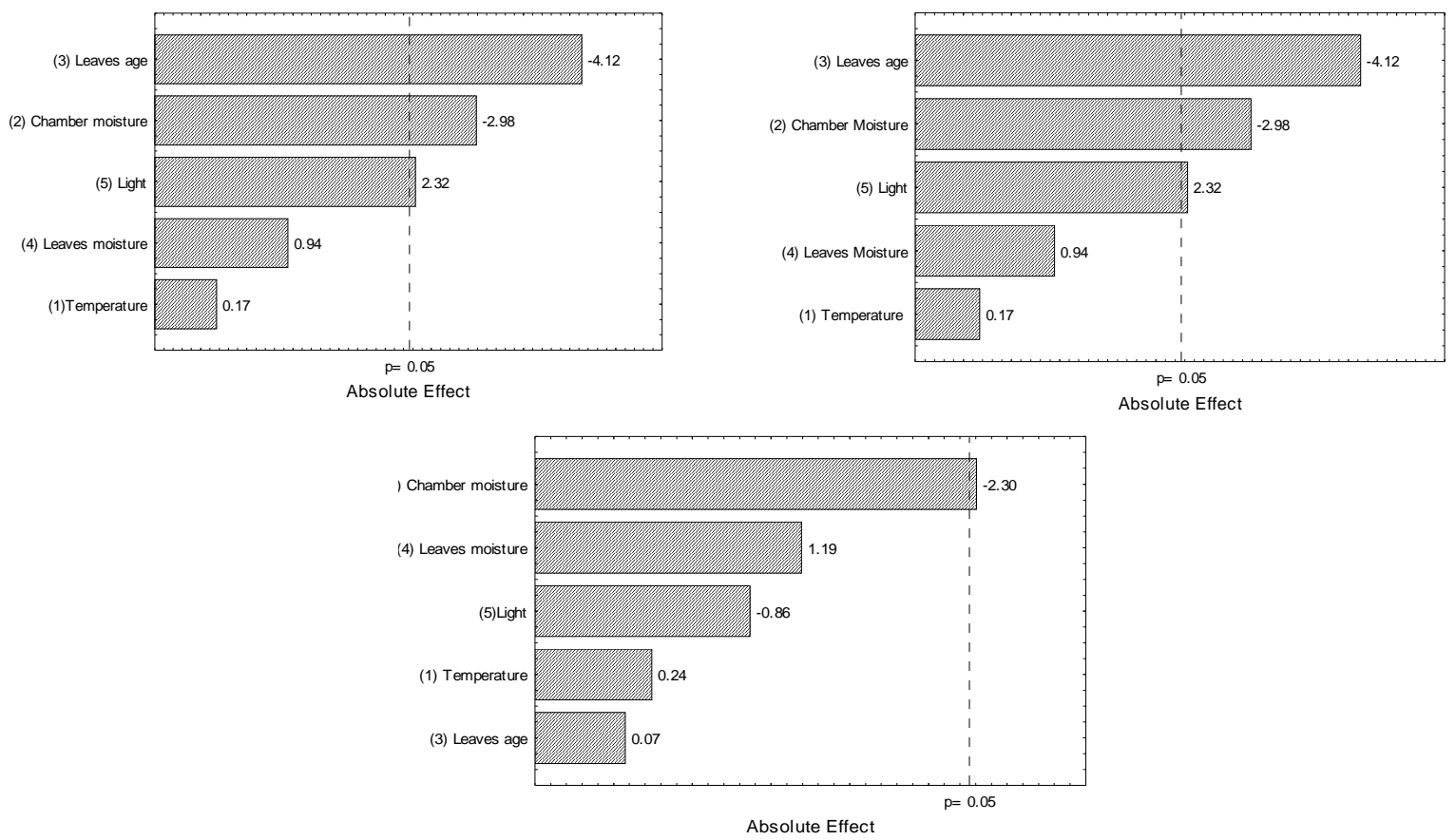

Figura 5 - Pareto chart of effects for color parameter L* after (a) $3 \mathrm{~h}$, (b) $6 \mathrm{~h}$ and (c) $48 \mathrm{~h}$ of oxidation.
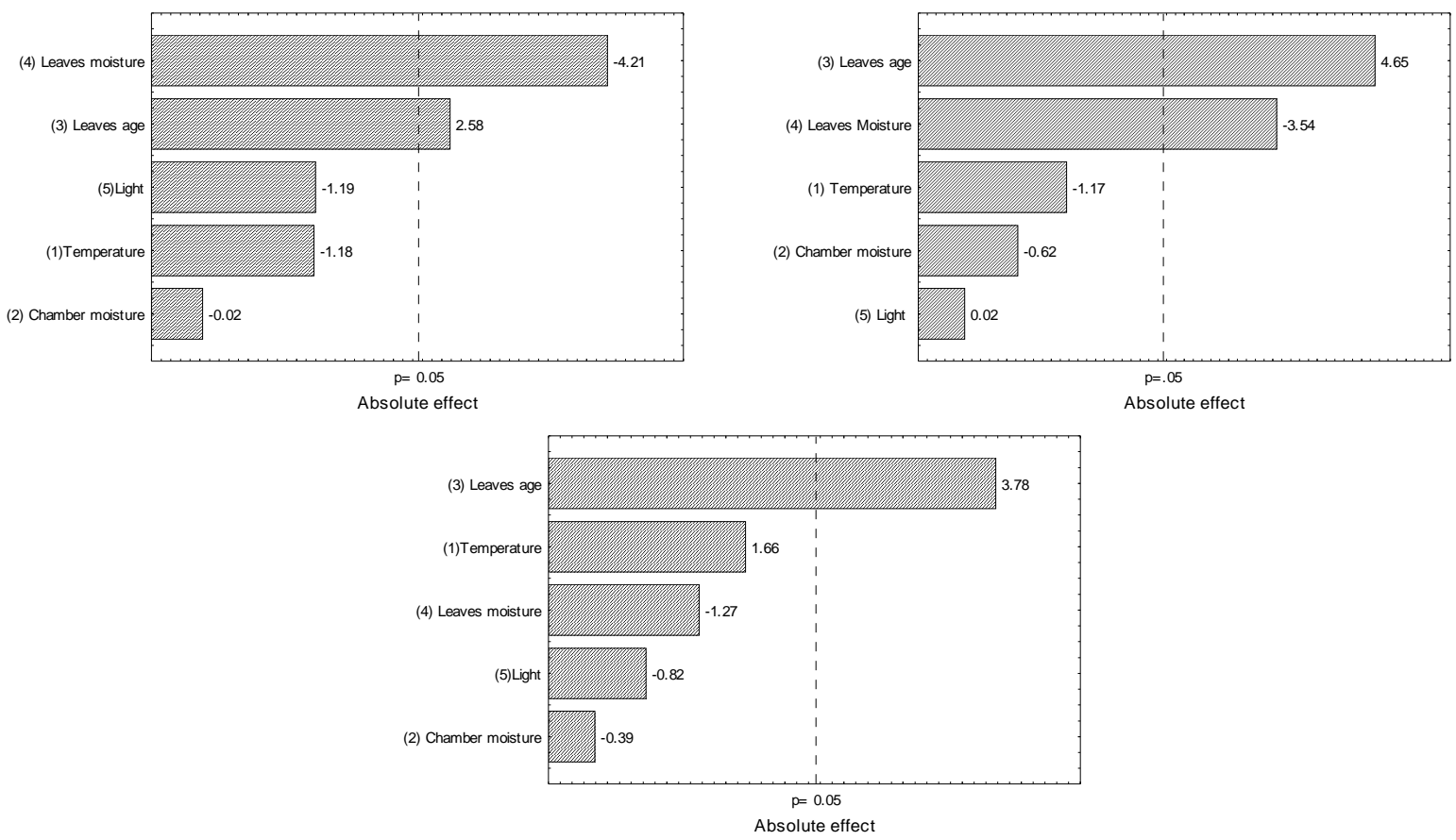

Figure 6 - Pareto chart of effects for color parameter a* after (a) $3 \mathrm{~h}$, (b) $6 \mathrm{~h}$ and (c) $48 \mathrm{~h}$ of oxidation. 

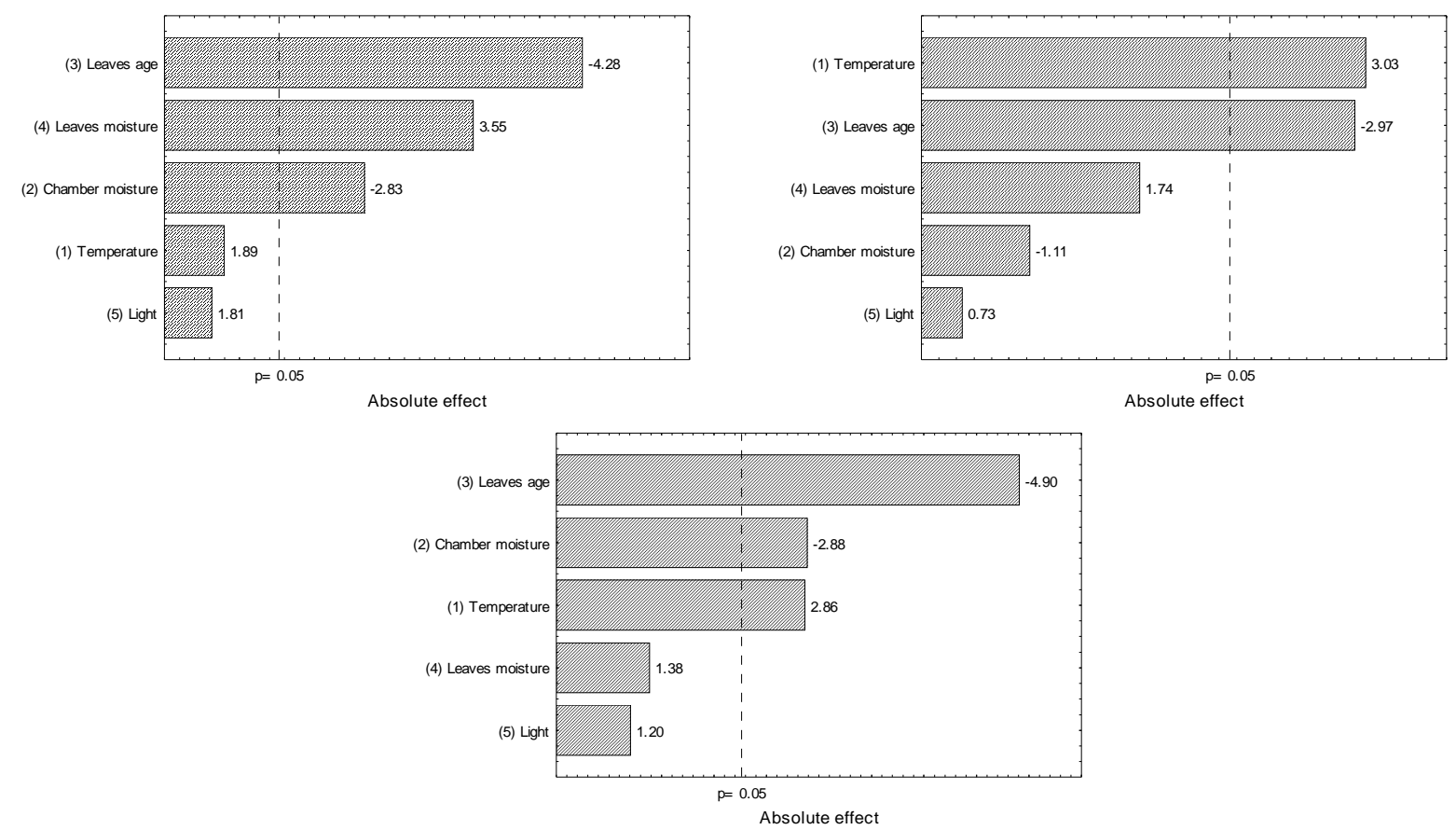

Figure 7 - Pareto chart of effects for color parameter b* after (a) $3 \mathrm{~h}$, (b) $6 \mathrm{~h}$ and (c) $12 \mathrm{~h}$ of oxidation.

Sinnecker et al (2002) showed that the parameter $\mathrm{L}^{*}$ for soybeans presented negative correlation with the concentration of total chlorophyll in the grains stored at $25^{\circ} \mathrm{C}$. The increase in the $\mathrm{L}^{*}$ followed the loss of chlorophyll. The loss of chlorophyll might be due to different factors such as $\mathrm{pH}$, enzymes, oxygen, temperature and light. Furthermore, the reaction of degradation of this pigment is determined by the water activity of the sample (Malheiros, 2007).

Obanda et al (2001) showed that the lightness (L*) of black tea was affected by the temperature rise and the time of oxidation. These authors showed that the lightness decreased as the oxidation develops. Muthumani and Kumar (2007) showed that the $\mathrm{L}^{*}$ for Camellia sinensis was affected by the content of theoflavines, while the content of taurobigines were responsible for changes in the color of the teas and alcoholic beverages.

In the present study, as the oxidation progressed, the $L^{*}$ parameter was less little affected by the studied factors, indicating that the browning of the leaves was achieving its maximum. The color parameter $\mathrm{a}^{*}$ indicated the variation from green to red. This parameter ranged from - $0.110(12 \mathrm{~h})$ to 8.080 ( $3 \mathrm{~h}$ ) for the conditions studied in the PB12 design. The negative values denoted that the green color was predominant in the ground leaves, except after $12 \mathrm{~h}$. When this parameter approached zero, the less saturated was the green color of the sample (Lawless; Heymann, 1999).

The age of the leaves presented a significant positive effect $(p<0.05)$ for the three oxidation times ( $3 \mathrm{~h}, 6 \mathrm{~h}$ and $48 \mathrm{~h}$ ), showing that the green color was lost in mature leaves (Fig. 6). The mature leaves presented a higher content of chlorophyll, and thus a more reddish color associated with the degradation of the pigment, when compared to the younger leaves.

The parameter $b^{*}$ denoted the variation of color between yellow and blue. Most of samples analyzed in the present work showed positive $b^{*}$, characteristic of yellow color. The factors that significantly influenced $b^{*}$ varied as the oxidation advanced. The older age of the leaves, however, always showed a negative effect on $b^{*}$, indicating that the mature leaves were less yellow. The older the leaves, the smaller was the rate of degradation of chlorophyll during oxidation, decreasing the intensity of yellow color of the product.

The temperature of incubation positively influenced the yellow color of the leaves after $6 \mathrm{~h}$ of incubation (Fig. 7). This suggested that higher temperatures led to a higher degradation of chlorophyll, turning the leaves more yellow. 


\section{CONCLUSIONS}

The factors that most influenced the oxidation of yerba maté were the relative humidity of the incubation chamber and the age of the leaves. However, these variables did not influence the $\mathrm{pH}$ and the color parameter a*. The statistically relevant results were obtained at 3,6,12 and $24 \mathrm{~h}$ of incubation. Young leaves presented higher enzymatic browning than mature leaves.

\section{REFERENCES}

Angayarkanni, J.; Muthusamy, P.; Murugesan, S; Swaminathan, K. (2002), Improviment of tea leaves fermentation with Aspergillus spp. J. Bioscience. 94, 299-303

Barhua, A. M.; Mahanta, P.K. (2003), Fermentation Characteristics of Some Assamica Clones and Process Optimization of Black Tea Manufacturing. J. Agr. Food. Chem., 51, 6578-6588.

Bassani, V. L.; Campos, A. M. (1997), Desenvolvimento de extratos secos e nebulizados de Ilex paraguariensis St. Hill; aquifoliáceae (ervamate) visando à exploração do potencial vegetal como fonte de produtos. $1^{\circ}$ Congresso Sul-Americano de Erva-Mate da Embrapa. Anais, Curitiba-PR.

Bastos, D. H. M.; Saldanha, L. A.; Catharino, R. R.; Sawaia, A. C. H. F.; Cunha, I. B. S.; Carvalho, P. O.; Eberlin, M. N. (2007), Phenolic antioxidants identified by ESI-MS from Yerba Mate (Ilex paraguariensis) and green tea (Camélia sinensis) extracts. Molecules., 12, 423-432.

Bhattacharyya, N.; Seth, S.; Tudu, B.; Tamuly, P.; Jana, A.; Ghosh, D.; Bandyopadhyay, R.; Bhuyan, M.; Sabhapandit, S. (2007), Detection of optimum fermentation time for black tea manufacturing using eletronic nose. Sensor Actuator. 122, 627-634.

Costa, S. G. (1989), A erva-mate. Curitiba: Editora UFPR, 86p.

Court, N. (2006), Fundamentals of water activity. Washington. 8 p. Disponível em: < http. www.dacagon.com/aqualab/>. Acesso em 28 set.

Deladino, L.; Anbinder, P. S.; Navarro, A. S.; Martino, M. N. (2007), Encapsulation of natural antioxidants extracted from Ilex paraguariensis. Carbohydr. Polym., 71, 126 - 134.

Delicado, E.N.; Megias, M.S.; Lopez, A.J.P.; Nicolás, J.M.L. (2007), Characterization of polyphenol oxidase from Napoleon grape. Food Chem, 100,108114.
Dziki, U.G.; Zlotek, U.; Świeca, M. (2008), Characterization of polyphenol oxidase from butter lettuce (Lactuca sativa var. capitata L.). Food Chem, 107, 129-135.

Dziki, U.G.; Szymanowska, U.; Baraniak, B. (2007), Characterization of polyphenol oxidase from broccoli (Brassica oleracea var. botrytis italica) florets. Food Chem, 105, 1047-1053.

Fennema, O. R. (2000), Química de los alimentos. 2. ed. Zaragoza: Acribia,.

Lawless, H. T.; Heymann, H (1999), Sensory evaluation of food. Maryland: Aspen Publishers.

Lehninger, A. L.; Cox, M. M.; Nelson, D. L. (2006), Princípios de Bioquímica. 4. ed. Editora Sarvier. São Paulo.

Liang, Y.; Lu, J.; Zhang, L.; Wu, S.; Wu, Y. (2002), Estimation of black tea quality by analysis of chemical composition and colour difference of tea infusions. Food Chem., 80, 283-290.

Liang, H.; Liang, Y.; Dong, J.; Lu, J.; Xu, H.; Wang, H. (2007), Decaffeination of fresh green tea leaf (Camellia sinensis) by hot water treatment. Food Chem.101, 1451-1456.

Lin, M. Ke, L.; Han, P.; Qiu, L.; Chen, Q.; Lin, H.; Wang, Q. (2010), Inhibitory effects of p-alkylbenzoic acids on the activity of polyphenol oxidase from potato (Solanum tuberosum). Food Chem, 119, 660663.

Mayer, A.M., (2006), Polyphenol oxidases in plants and fungi: going places? A review. Phytochemistry 67, 2318-2331.

Malheiros, G. C (2007), Estudo da alteração da cor e degradação da clorofila durante a armazenagem de erva-mate tipo chimarrão. Universidade Federal de Santa Maria - RS.

Marx, F.; Janssens, M. J. J.; Urfer, P.; Scherer, R. (2003), Caffeine and Theobromine Composition of Mate (Ilex paraguariensis) Leaves in Five Plantations of Missiones, Argentina. Plant. Food Hum. Nutr., 58, $1-8$.

Mazuchowski, J. Z.; Rucker, N. G. A. (1997), Prospecção tecnológica da cadeia produtiva da ervamate. Curitiba - PR: Secretaria de estado da agricultura e do abastecimento, p.130.

Muthumani, T.; Kumar, R. S. S. (2007), Influence of fermentation time on the development of compounds responsible for quality in black tea. Food Chem., 101, 98-102.

Nagai, T; Suzuki, N. (2003), Polyphenol oxidase from bean sprouts (Glicine max L.) J. Food Sci., 68, 16-20.

Nakasaki, K.; Abe, M.; Takaoka, N.; Idemoto, Y.; Takagi, C.; Imai, T. (2008), Characteristic fungi observed in the fermentation process for Puer tea. Int. J. Food Microbiol., 124, 199-203. 
Niu, S.; Xu, P.; Fang, Y.; Zhang, L.; Yang, Y.; Liao, X.; Hu, X. (2010), Comparative study on cloudy apple juice qualities from apple slices treated by high pressure carbon dioxide and mild heat. Innov Food Sci Emerg, 11, 91-97.

Obanda, M.; Owuor, P.; Mangoka, R. (2001), Changes in the chemical and sensory quality parameters of black tea due to variations of fermentation time and temperature. Food Chem., 75, 395-404.

Obanda, M. et.al. (2004), Changes in thearubigin fractions and theaflavin levels due to variations in processing conditions and their influence on blazck tea liquor brightness and total colour. Food Chem., 85, 163-173.

Ramallo, L. A.; Albani, O. A. (2004), Prediction and determination of water uptshe in packaged yerba mate. Food Sci. Technol. Int., 10, 35-40.

Riegel, R. E. (2006), Bioquímica. São Leopoldo: UNISINOS, p.547.

Rodrigues, M. I.; Iemma, A. (2005), Planejamneto de experimentos e otimização de processos. Campinas: Casão do Pão, p. 251
Saldanha, M. D. A.; Mazzafera, P.; Mohamed, R. S. (1999), Extraction ofpurine alkaloids from mate (Ilex paraguariensis) using supercritical $\mathrm{CO}_{2}$. J. Agr Food Chem., 47, $3804-3808$.

Schamalko, M. E.; Scipioni, P. G.; Ferreyra, D. J. (2005), Effect of water activity and temperature in color and chlorophylls changes in yerba mate leaves. Int. J. Food Prop., 8, 313-322.

Silva, J. A. (2000), Tópicos da tecnologia de alimentos.São Paulo: Varela, 231p.

Sinnecker, P.; Gomes, M. S. O.; Arêas, J. A. G.; Lanfer-Marquez, U.M. (2002), Relationship between color (instrumental and visual) and chlorophyll contents in soybean seeds during ripening. J. Agr. Food Chem., 50, 3961-39.

Wu, Y.; Pan, L.; Yu, S.; Li, H. (2010), Cloning, microbial expression and structure-activity relationship of polyphenoloxidases from Camellia sinensis. J Biotechnol, 145, 66-72.

Received: January 26, 2010; Revised: July 29, 2010; Accepted: January 06, 2011. 